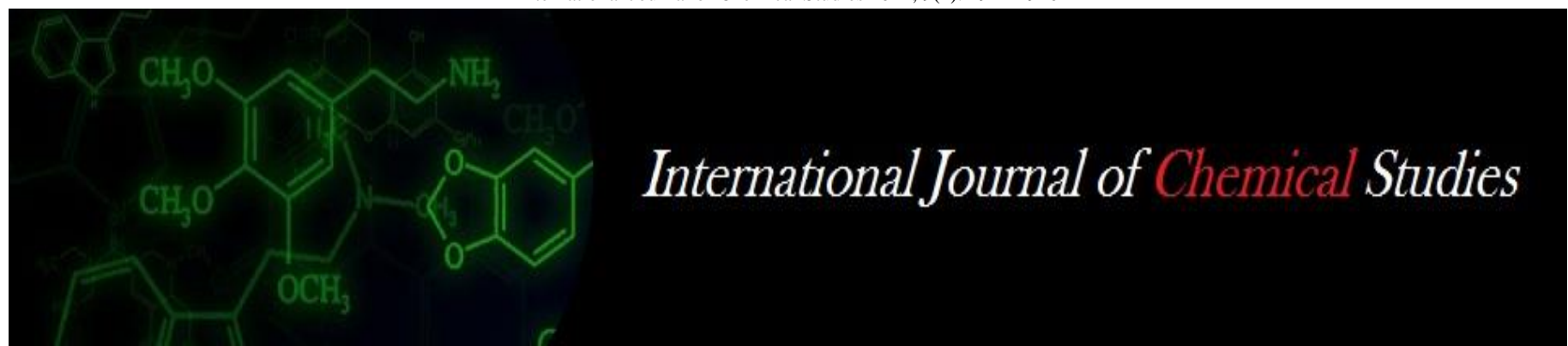

P-ISSN: 2349-8528

E-ISSN: 2321-4902

www.chemijournal.com

IJCS 2021; 9(1): 1911-1916

(C) 2021 IJCS

Received: 08-11-2020

Accepted: 15-12-2020

Vaishampayan Sanjay

Senior Scientist, Department of

Entomology, Jawaharlal Nehru

Krishi Vishwa Vidyalaya

Jabalpur, Madhya Pradesh,

India
Corresponding Author: Vaishampayan Sanjay Senior Scientist, Department of Entomology, Jawaharlal Nehru Krishi Vishwa Vidyalaya Jabalpur, Madhya Pradesh, India

\section{Study of the taxonomic distribution of insect fauna collected in light trap with different light sources during Rabi season at Jabalpur (M.P.)}

\author{
Vaishampayan Sanjay
}

DOI: https://doi.org/10.22271/chemi.2021.v9.i1aa.11501

\begin{abstract}
The experiment was carried out at JNKVV Jabalpur (MP) to study the taxonomic distribution of insect pest species collected in light trap with various light sources viz. MV $125 \mathrm{w}$ bulb, UV $8+8 \mathrm{w}$ tubes and LED (White) $15 \mathrm{w}$ bulb.

The analysis revealed that 31 insect species belonging to 10 orders and 23 families were recorded throughout the season (Rabi 2016-17). These species were grouped in two major categories. Among the harmful crop pest group 22 species collected under 5 orders and 14 families (total collection was 15599 insects). Order Lepidoptera was represented by the highest number of 6 families including 13 species followed by the order Hemiptera. Group of beneficial insects as natural bio control agents represented by 6 orders and 9 families (total collection was 2114 insects). Comparing the relative size of trap catches the highest catch was observed of Dorylus sp. (1492 wasps) among all the order followed by Hydrochara caraboides Latreille ( 316 beetles).
\end{abstract}

Keywords: Light trap, light source, UV, MV, insect fauna, texanomic distribution

\section{Introduction}

It is well known that insects fly toward streetlight or other outdoor illumination at night. This innate phototactic behavior has provided the basis of the design of electric insect trap. Equipped with UV-emitting fluorescent tubes, the light trap effectively attract insects such as moths and beetles and prevent these insects from entering into fields, greenhouses and stores that are open at night. In recent years, considerable interest has been generated in pest control technology that utilizes the responses of insects to light as a "clean" form of pest control that does not use synthetic pesticides (Emura and Tazawa 2004; Honda 2011; Tazawa 2009) ${ }^{[1,4,9]}$. The key insect pests of cereal crops, pulse crops, vegetable crops, horticultural crops can be mass trapped by using the light trap. Farmers must know that by attracting and killing one adult moth or insect they control around 500-600 insect progenies through them (Vaishampayan 2007) ${ }^{[11]}$.

In recent years, as a non-chemical method for insect pest control, light traps have been widely used to control agricultural pests in developing countries (Vaishampayan and Vaishampayan 2016) ${ }^{[12]}$. In China, currently commercial light traps are being used by the Chinese Ministry of Agriculture to control agricultural pests over an area of more than 32 million ha. (Ma et al. 2009) ${ }^{[5]}$. The use of light traps for controlling insect pests is restricted since they kill both pests and beneficial insects. It may be a possible to reduce the numbers of beneficial insects trapped by adjusting nightly trapping time based on differences recorded in the timing of the nocturnal flight peaks of target pests and beneficial (Ma and Ma 2012) ${ }^{[6]}$.

\section{Materials and Methods}

The experiment was conducted at JNKVV Jabalpur (MP) during the period between first week of January to last week of April, 2017. Light Trap models SMV- 4 developed by Dr. S. M. Vaishampayan in 2014, were used in the present study. Traps are suitable to use Mercury Vapour (MV), Ultra Violet (UV) and Light Emitting Diode (LED) lamps as light source. The insects collected in the collection bag were killed by the exposure of Dichlorvas $76 \mathrm{EC}$ vapors (as fumigating agent) released in a dispenser with scrubber, placed in a collection tray for 
instant killing of trapped insects. Light traps were operated every night and collection was observed next morning. Total insects fauna was observed and sorted out on the basis of major species and order groups. Data of daily trap catch was maintained. In all, three light traps were installed in the experimental area. This area was covered mainly by a gram crop in around 30 hectors of crop area. Spacing between each trap was approximately 100 meter. The data were subjected to statistical analysis

\section{Results and Discussion}

The research experiments were carried out to study the taxonomic distribution of insect pest species towards various light sources viz. Light trap with MV 125 watt bulb (T1), UV 8+8 watt tubes (T2), LED (White) 15 watt bulb (T3). Observations of species wise total trap catches per day/ treatment (Light source) that is T1, T2, and T3 were recorded. The month wise catches were represented in following table no. 1 .

Table 1: Insect fauna collected in light trap during Rabi season (2016-17) at Jabalpur

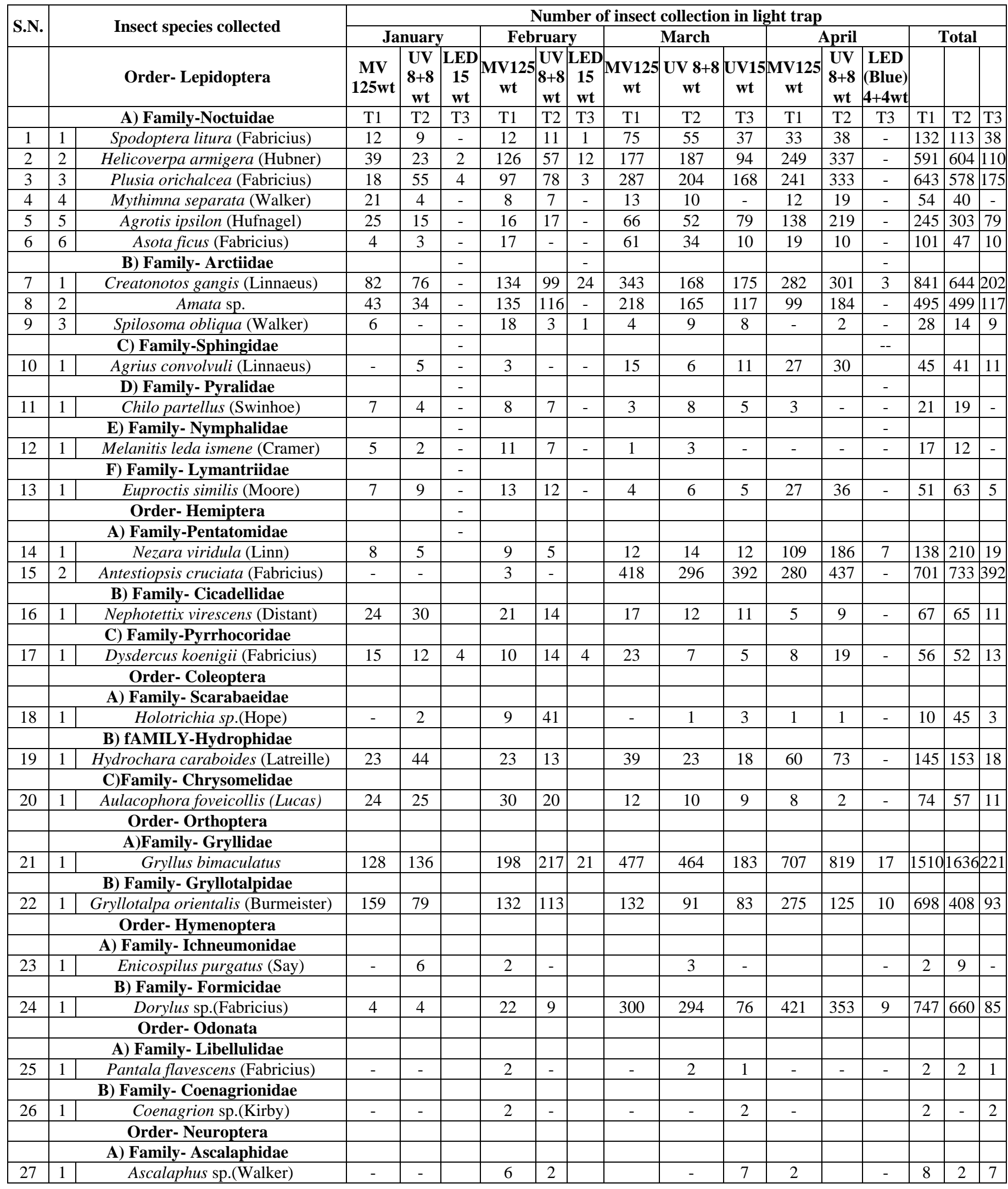




\begin{tabular}{|c|c|c|c|c|c|c|c|c|c|c|c|c|c|c|c|c|}
\hline & & B) Family- Chrysopidae & & & & & & & & & & & & & & \\
\hline \multirow[t]{3}{*}{28} & 1 & Chrysoperla sillemi (Esben-petersen) & 5 & 35 & 21 & 15 & 11 & 17 & 2 & 23 & & 36 & - & 43 & 88 & 34 \\
\hline & & Order- Diptera & & & & & & & & & & & & & & \\
\hline & & A) Family- Bibionidae & & & & & & & & & & & & & & \\
\hline \multirow[t]{3}{*}{29} & 1 & Plecia amplipennis (Skuse) & - & 4 & 23 & 42 & & 375 & 285 & 168 & 239 & 197 & - & 637 & 528 & 168 \\
\hline & & Order- Dermaptera & & & & & & & & & & & & & & \\
\hline & & A) Family- Forficulidae & & & & & & & & & & & & & & \\
\hline \multirow[t]{3}{*}{30} & 1 & Elaunon bipartitus (Kirby) & 9 & 26 & 12 & 9 & & 3 & - & 2 & 34 & - & - & 58 & 35 & 2 \\
\hline & & Order- Dictyoptera & & & & & & & & & & & & & & \\
\hline & & A) Family- Mentidae & & & & & & & & & & - & & & & \\
\hline 31 & 1 & Archimantis latistyla (Serville) & 4 & - & 2 & 1 & & - & - & 2 & - & & - & 6 & 1 & 2 \\
\hline
\end{tabular}

To study the relative size of trap catches of various species collected in different taxonomic groups, collection of entire season (January to April-2017). Was recorded species wise given in Table 1. These species were grouped on the basis of their economic importance in two major categories viz. Harmful insects- as crop pests in Table 2 and beneficial insects- as bio-control agents (Predators and parasites) were given in Table 3.

\section{Group-I) Harmful insects- as crop pests}

Among the harmful crop pest species order Lepidoptera was represented by the highest number of 6 families including 13 species. The family Noctuidae has the highest 6 species (Fig.1) which includes most important pests of different crops. Among these Plusia orichalcea (Fabricius) has the highest size of trap catch (1396 moths) followed by Heliothis armigera (1305 moths), while the lowest size of trap catch was of Melanitis leda (29 moths) (Table-2). Five major polyphagous pest species of Lepidoptera namely, Spodoptera litura Fabricius (283 moths), Mythimna separata (94 moths), Helicoverpa armigera (Hubber) (1365 moths), Plusia orichalcea (1396 moths), and Agrotis ipsilon (Hufnagel) (627 moth) were also recorded during the season in trap catch. After Lepidoptera, Hemiptera was the next highest order of pest species in trap catches with 3 families and 4 species. The family Pentatomidae is represented by Antestiopsis cruciata (Fabricius) with a highest trap catch of (1826 bugs) followed by Nezara viridula (Linnaeus) (367 bugs), Nephotettix virescens (Distant) (143 hoppers) and Dysdercus koenigii (Fabricius) (121 bugs) Order Coleoptera was represented by 2 families and 2 species viz. family Chrysomelidae,
Aulacophora foveicollis (Lucas) (142 beetles), family Scarabidae, Holotrichia consanguinea (Blanch) (58 beetles). Order Orthoptera was represented by 2 families and 2 species. Among two species of this order highest trap catch was of Field cricket, Euscyrtus concinnus (de Haan) (3367 crickets) followed by Mole cricket, Gryllotalpa orientalis (Burmeiste)r (1191 crickets).

Order Diptera was represented by one family i.e. Bibionidae with single species Plecia amplipennis (Skuse) (1333 flies).

\section{Group- II) Beneficial insects- as bio-control agents}

Order Hymenoptera was represented by 2 families and 2 species as parasites viz. Dorylus sp. (1492 wasps) has the highest trap catch followed by Enicospilus purgatus (Say) (11 wasps). Order Odonata also represented two species namely Coenagrion sp. (4 flies) and Pantala flavescens (Fabricius) (5 flies) which belongs to family Coenagrionidae and Libellulidae respectively. Order Neuroptera was represented by two species namely Ascalaphus sp. (17 flies) and Chrysoperla sillemi (Esben-petersen) (165 green lacewings) which belongs to family Ascalaphidae and Chrysopidae respectively. Order Dermaptera, Dictyoptera and Coleoptera were represented by only one species each i.e. Earwig, Elaunon bipartitus (Kirby) (95 earwigs) family Forficulidae; Praying mantis, Archimantis latistyla (Serville) (7 mantis) family Mentidae and Hydrochara caraboides Latreille (316 beetles) family Hydrophilidae respectively.

Comparing the relative size of trap catches the highest catch was observed of Dorylus sp. (1492 wasps) among all the order followed by Hydrochara caraboides Latreille (316 beetles).

Table 2: Taxonomic distribution of insect fauna collected in light trap during Rabi season (2016-17) at Jabalpur (Group-I) Harmful insects- as crop pests

\begin{tabular}{|c|c|c|c|}
\hline $\begin{array}{l}\text { S. } \\
\text { No. }\end{array}$ & Insect species collected & $\begin{array}{l}\text { Total of seasons collection } \\
\text { (January to April.) }\end{array}$ & $\begin{array}{c}\text { Economic status } \\
\text { As crop pest } \\
\end{array}$ \\
\hline \multicolumn{4}{|c|}{ Order- Lepidoptera } \\
\hline & A) Family-Noctuidae & & \\
\hline 1 & Plusia orichalcea (Fabricius) Cabbage semilooper & 1396 & $\begin{array}{c}\text { Major polyphagous pest of vegetable crops, cabbage, } \\
\text { cauliflower etc. }\end{array}$ \\
\hline 2 & Helicoverpa armigera (Hubner) Gram pod borer & 1305 & $\begin{array}{l}\text { Major polyphagous pest of pulses, potato, tomato, chilli, } \\
\text { okra and cotton. }\end{array}$ \\
\hline 3 & Mythimna separata (Walker) Army worm & 94 & Major pest of paddy. \\
\hline 4 & Spodoptera litura (Fabricius) Tobacco caterpillar & 283 & $\begin{array}{c}\text { Major polyphagous pest of soybean, cabbage, cucurbits, } \\
\text { potato, chilli and pea etc. }\end{array}$ \\
\hline 5 & Asota ficus (Fabricius) & 198 & Fodder pest \\
\hline \multirow[t]{2}{*}{6} & Agrotis ipsilon (Hufnagel) Cutworm & 627 & $\begin{array}{c}\text { Major polyphagous pest of pulses, pest of cabbage, } \\
\text { cucurbits, potato. }\end{array}$ \\
\hline & B) Family- Arctiidae & & \\
\hline 7 & Creatonotos gangis (Linnaeus) Tiger moth & 1687 & Polyphagous pest. \\
\hline 8 & Amata sp. Seven spotted moth & 1111 & Fodder pest. \\
\hline \multirow[t]{2}{*}{9} & Spilosoma obliqua (Walker) Bihar hairy caterpillar & 57 & $\begin{array}{c}\text { Major polyphagous pest of sesame, linseed and minor pest } \\
\text { of cabbage and sweet potato }\end{array}$ \\
\hline & C) Family-Sphingidae & & \\
\hline 10 & Agrius convolvuli (Linnaeus) & 97 & Major pest of sweet potato, sunflower and soybean \\
\hline
\end{tabular}




\begin{tabular}{|c|c|c|c|}
\hline & Spingid moth & & \\
\hline & D) Family- Pyralidae & & \\
\hline \multirow[t]{2}{*}{11} & Chilo partellus (Swinhoe) Maize stem borer & 40 & Major pest of maize and sorghum \\
\hline & E) Family- Nymphalidae & & \\
\hline \multirow[t]{2}{*}{12} & Melanitis leda ismene (Cramer) Rice butter fly & 29 & Major pest of paddy \\
\hline & F) Family- Lymantriidae & & \\
\hline \multirow[t]{4}{*}{13} & Euproctis similis (Moore) & 119 & Minor pest of paddy and ragi \\
\hline & G) Family- Crambidae & & \\
\hline & Order-Hemiptera & & \\
\hline & A) Family-Pentatomidae & & \\
\hline 14 & Nezara viridula (Linnaeus) Green stink bug & 367 & $\begin{array}{c}\text { Major polyphagous pest of soybean, pigeon pea and } \\
\text { vegetable crops }\end{array}$ \\
\hline \multirow[t]{2}{*}{15} & Antestiopsis cruciate (Fabricius) Coffee plant bug & 1826 & Pest of coffee and jasmine \\
\hline & B) Family- Cicadellidae & & \\
\hline \multirow[t]{2}{*}{16} & Nephotettix virescens (Distant) Green leaf hopper & 143 & Major pest of paddy \\
\hline & D) Family-Pyrrhocoridae & & \\
\hline \multirow[t]{3}{*}{17} & Dysdercus koenigii (Fabricius) Red cotton bug & 121 & Major pest of cotton and okra \\
\hline & Order- Coleoptera & & \\
\hline & A) Family-Scarabaeidae & & \\
\hline \multirow[t]{2}{*}{18} & Holotrichia consanguinea White grub & 58 & Major pest of ground nut, sugarcane, chilli and soybean \\
\hline & Family- Chrysomelidae & & \\
\hline \multirow[t]{3}{*}{19} & Aulacophora foveicolis (Lucas) & 142 & Major pest of cucurbitaceous particularly pumpkin \\
\hline & Order- Orthoptera & & \\
\hline & A) Family- Gryllidae & & \\
\hline \multirow[t]{2}{*}{20} & Gryllus bimaculatus Field cricket & 3367 & Pest of fodder grasses \\
\hline & C) Family- Gryllotalpidae & & \\
\hline \multirow[t]{3}{*}{21} & Gryllotalpa orientalis (Burmeister) Mole cricket & 1199 & Pest of paddy \\
\hline & Order- Diptera & & \\
\hline & A) Family- Bibionidae & & \\
\hline \multirow[t]{2}{*}{22} & Plecia amplipennis (Skuse) & 1333 & Fodder pest \\
\hline & Family- Calliphoridae & & \\
\hline
\end{tabular}

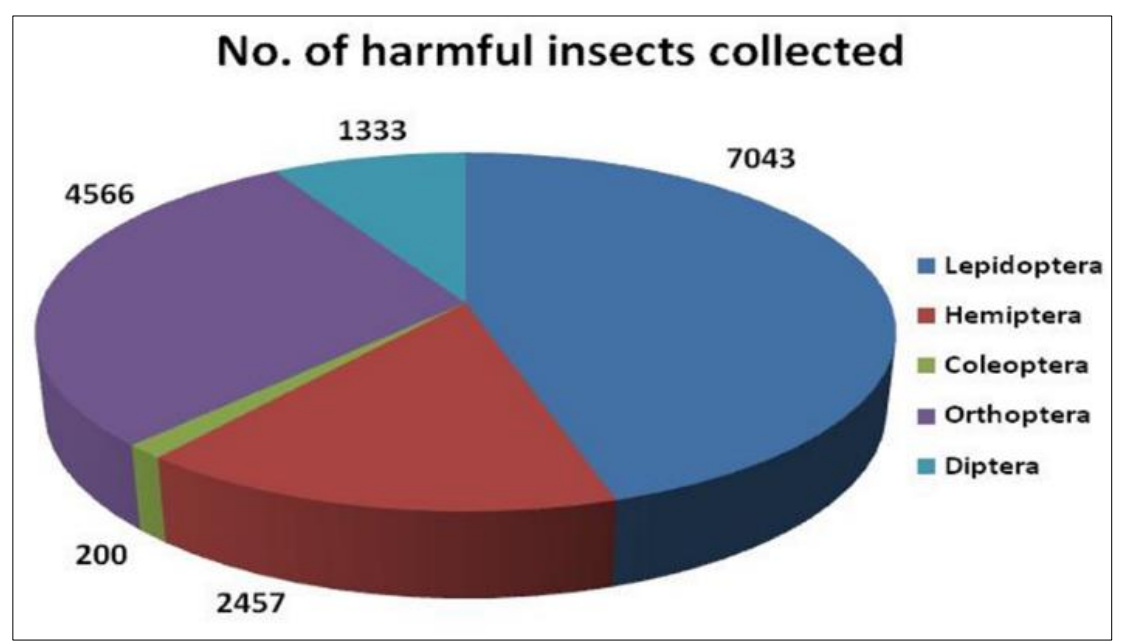

Fig 1: No. of harmful insects- as crop pests of different order collected in light trap

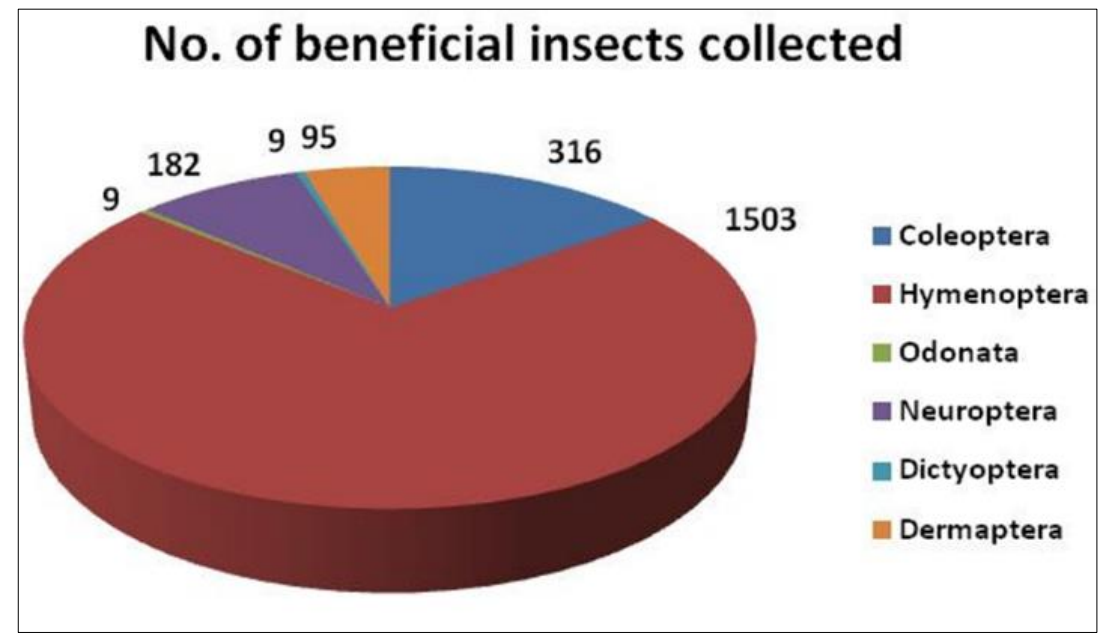

Fig 2: No. of beneficial insects (predators) of different order collected in light trap 1914 
Table 3: Taxonomic distribution of insect fauna collected in light trap during Rabi season (2016-17) at Jabalpur (Group- II) Beneficial insectsas bio-control agents (Predators and parasites)

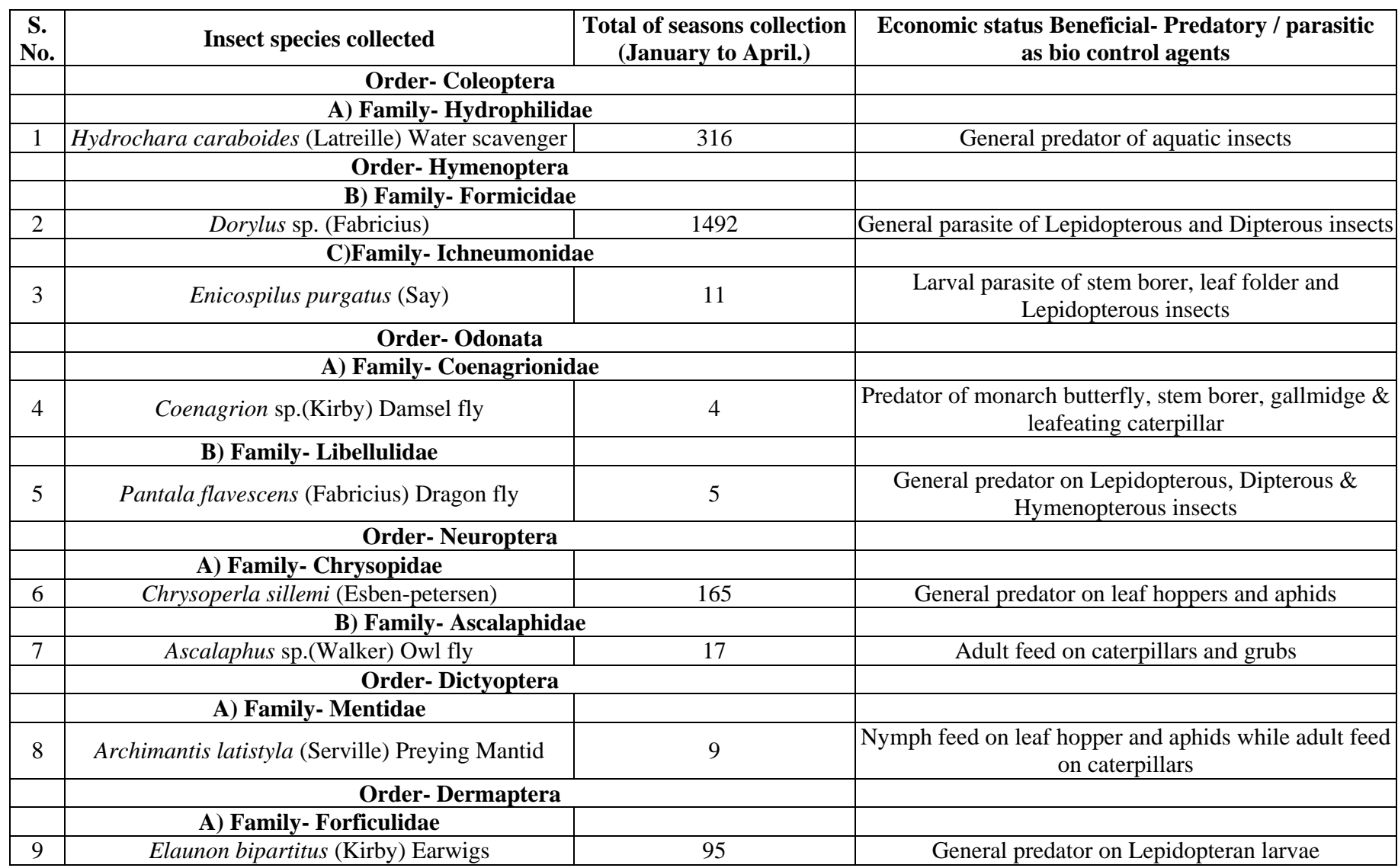

Muchala (2014) ${ }^{[7]}$ revealed that 69 species belonging to 11 orders and 37 families were recorded throughout the season (kharif 2013). Based on number of species collected, largest collection was represented by order Lepidoptera (20 species), followed by orders Hemiptera (15 species), Coleoptera (15 species), Orthoptera (6 species) \& Hymenoptera (5 species) in descending order respectively and natural bio-control agents were represented by 7 orders, 15 families \& 25 species as predators and 1 order, 3 families \& 4 species as parasites.

Sharma et al. (2010) ${ }^{[8]}$ conducted a study during kharif 2004 to document the scope of light traps as integrated pest management tool in paddy ecosystem at Jabalpur region of Madhya Pradesh. A total of 62 species were recorded during the cropping season of paddy, belonging to 8 orders and 33 Families. Lepidoptera was the largest Order with 27 species, followed by Hemiptera (14 species), Coleoptera (12 species) and Orthoptera (4 species). Odonata, Hymenoptera, Isoptera and Dictyoptera were the other orders of minor significance. Based on economic importance, this collection was represented by 45 species of harmful insects (as crop pests) and 17 species of predatory insects (useful as bio-control agents).

Upadhyay et al. (2000) ${ }^{[10]}$ also reported that a total of 17 predatory species belongs to 9 families and 4 parasitic species belongs to 2 families collected through light trap in Jabalpur. Among the predatory species Coleopterous insects were the most predominant, represented by 3 families Coccinellidae, Carabidae and Cicindelidae respectively.

Goel (1976) ${ }^{[3]}$ observed 17 families of Coleoptera trapped at light including 89 species of Carabidae and 13 species of Coccinellidae in North India. Ghorpade (1979) [2] from Karnataka recorded 8 species of Coccinellides (Coleoptera) collected in light trap.

\section{References}

1. Emura K, Tazawa S. The development of the ecoengineering insect control technology-physical control of insect behavior using artificial lights. Eco-engineering 2004; 16:237-240.

2. Ghorpade KD. On some Coccinellidae (Coleoptera) attracted to light. Current Research 1979;8(70):113-114.

3. Goel SC. Phenology and relative abundance of Coleoptera in light trap in Northern India. Utter Pradesh Journal of Zoology 1, 108-115.

4. Honda KO. Reactions to light in insects and practical applications J Soc Biomech 2011;35:233-236.

5. Ma CS, Ma Gang, Chang XQ, Yang HP. Environment friendly methods for controlling cotton bollworm moths, Helicoverpa armigera. Chin. J Environ. Entomol 2009;31:220-226.

6. Ma Gang, Ma Chun-Sen. Differences in the nocturnal flight activity of insect pests and beneficial predatory insects recorded by light traps: Possible use of a beneficial-friendly trapping strategy for controlling insect pests Eur. J Entomol 2012;109(3):395-401.

7. Muchhala Y. Study on insect pest fauna of paddy ecosystem collected in light trap in Jabalpur region. M.Sc. Thesis, JNKVV, Jabalpur 2014, 1-109.

8. Sharma AK, Barche S, Mishra PK. Pest and predatory insect species inhabiting paddy ecosystem in Jabalpur, Madhya Pradesh collected with the help of light traps. Pest Management and Economic Zoology 2010;18(1/2):125-133.

9. Tazawa S. Artificial lighting for agricultural applications. J Jpn Soc Agric Machin 2000;71:19-25.

10. Upadhyay RN, Dubey OP, Vaishampayan SM. Studies on the common predatory and parasitic species of insects 
collected on light trap. JNKVV Research Journal 2000;33(1/2):50-57.

11. Vaishampayan SM. Utility of light trap in Intergrated Pest Management. In: Entomology: Novel Approaches. Eds: PC. Jain and MC Bhargava. New India Publishing Agency, New Delhi 2007, 193-210.

12. Vaishampayan SM, Vaishampayan Sanjay. Light trap: An Ecofriendly IPM tool. Book published by Daya Publishing House a division of Astral International Pvt. Ltd. New Delhi 2016, 108. 